Please do not remove this page

RMIT

UNIVERSITY

\title{
Towards a broadloid press approach: The transformation of China's newspaper industry since the 2000s
}

Huang, Chengju

https://researchrepository.rmit.edu.au/esploro/outputs/9921862034001341/filesAndLinks?institution=61RMIT_INST\&index=null

Huang, C. (2016). Towards a broadloid press approach: The transformation of China's newspaper industry since the 2000s. Journalism, 17(5), 652-667. https://doi.org/10.1177/1464884915579331

Document Version: Accepted Manuscript

Published Version: https://doi.org/10.1177/1464884915579331

Repository homepage: https://researchrepository.rmit.edu.au

(c) The Author(s) 2015

Downloaded On 2023/04/26 19:33:40 +1000

Please do not remove this page 
Thank you for downloading this document from the RMIT Research Repository.

The RMIT Research Repository is an open access database showcasing the research outputs of RMIT University researchers.

RMIT Research Repository: http://researchbank.rmit.edu.au/

\section{Citation:}

Huang, C 2016, 'Towards a broadloid press approach: The transformation of China's newspaper industry since the 2000s', Journalism, vol. 17, no. 5, pp. 652-667.

See this record in the RMIT Research Repository at:

https://researchbank.rmit.edu.au/view/rmit:31268

Version: Accepted Manuscript

Copyright Statement: (c) The Author(s) 2015

Link to Published Version:

http://dx.doi.org/10.1177/1464884915579331

\section{PLEASE DO NOT REMOVE THIS PAGE}




\section{Towards a broadloid press approach: The transformation of China's newspaper industry since the 2000s}

China's newspaper industry is currently sitting at the crossroads of stagnation or innovation. As of the end of 2011, China had 1,928 newspaper titles, generating a combined annual circulation of nearly 46.74 billion copies (Tang, 2012). The industry's total turnover reached RMB74.3 billion by the end of 2012 (Cui, 2013: 7). But daily newspapers' readership penetration rate has experienced a downturn trend since the 2000s (e.g., down from $70.6 \%$ in 2001 to $65.7 \%$ in 2007 [Sun and Liu, 2009: 7]). More importantly, the industry's advertising income has dropped significantly over the years in spite of generally stable circulation (e.g., in 2012, the industry's advertising income dropped $7.5 \%$ [Yao, 2013: 82] while circulation was down 3.09\% [Tian, Cai and Cui, 2013] on a year-on-year basis). This rapidly decreasing interest from advertisers in newspapers reflects typically the fast changing demographics of newspaper readership in China. On the one hand, the younger generation (particularly urban youth as the major purchasing power), like their peers in the West, give newspapers only scant notice; on the other hand, the current newspaper readership as a whole is rapidly aging (currently more than 42 years old by average [Yao, 2013: 90]). In the meantime, the industry also faces many internal challenges, primarily a high degree of mimetic isomorphism in terms of both journalistic approach and business model and poor professional and ethical 
standards. There is growing evidence to suggest that the industry has reached journalistic and growth stagnation. This invites urgent theoretical innovation to tackle the ways for sustainable development of the industry.

Though much has been written about China's changing news media industries and journalistic environment since the 2000s in the English-language research literature (e.g., Huang, 2007; Lee, 2003; Pan, 2000; Yu, 2011; Zhang, 2010; Zhao, 2000, 2008), there has been little specific and systematic investigation of the newspaper sector, particularly in terms of its macro structural change and journalistic orientation. Within China, while continuing research interest in print journalism in the past decade or so has generated numerous publications (e.g., see Lai, 2009; Qi, 2011; Zhao, 2006), most of them are reflective essays published in non-referred trade or academic journals and have a profound lack of systematic investigation and critical contextualisation. As an attempt to bridge this research gap, this study examines the changes and challenges of China's newspaper industry by focusing on the popular press sector that has dominated the daily newspaper market since the early 2000 s. Specifically, this study investigates the following three key issues: 1) the dramatic expansion of the popular press sector at the expense of the Party organ sector in the early and middle 2000s; 2) the stagnation of the popular press sector since then in spite of its efforts to experiment with a so-called 'mainstream' press in the second half of the decade; and 3) this study's call for a 'boradloid' press approach in response to this stagnation. This study is mainly based on data collected from relevant bluebooks, survey/research reports, and 
trade and academic journal articles on Chinese journalism published in Chinese language, as well as my critical reading of some leading Chinese daily newspapers' everyday news coverage. To make sense of these data, I critically analyse them by placing them into context and by using my knowledge based on decades of close observation of Chinese politics and journalism.

Conceptually, aiming to theoretically revitalise the currently deadlocked debate on further reforms of China's popular press sector between liberal and conservative critics, this study finds the idea of 'broadloid' particularly inspiring in tackling a meaningful third way. Coined by The Guardian's current editor Alan Rusbridger, broadloid as a term has to date been nearly solely used in the Western context and often in a rather negative way by critical scholars to describe 'a growing tendency of broadsheet newspapers to adopt the stories and styles of tabloid reporting' (Franklin, 2005a: 28). It has also been used to refer to a popularised/tabloided broadsheet title in the West (such as The Guardian itself) as a result of this tendency. There has been little, if any, discussion, of how the term may be expanded and redefined as a more general press concept that may be used in broader and diverse contexts. Aiming at exploring such theoretical potential of the term, this study redefines broadloid as a press concept that serves as a sensible and vibrant middle-ground way out for mainstream newspapers in diverse social and journalistic contexts in their search for new journalistic directions to copy with the rapidly changing socialdemographical and communication technological environments in the $21^{\text {st }}$ century. Specifically, the implications of this redefinition are three-fold. First, 
broadloid may be understood as a popularised quality press approach that pays close attention to, and aims to strike a dynamic balance between, newspaper quality and readability. Quality without readability can hardly survive in the marketplace; readability without quality may substantially compromise newspapers' social responsibility. Given newspaper titles thus must keep this basic and core value of the approach in mind no matter which path of, and what specific approach to, broadloidisation they may take. Second, broadloid may also refers to a popularised quality newspaper title that may result via either the normative path of the so-called 'dumbing down' of a serious-broadsheet paper or the 'wising up' of a tabloid title as an alternative path. Third, while popularised quality newspaper titles in the West such as The Times and The Guardian in the UK may be seen as the ideal or normative version of broadloid, there may be a variety of transitional or alternative versions in the case of the broadloidisation of tabloid titles (as this path of broadloidisation is likely to be more journalistically, and in certain circumstances politically, challenging). As will be clear, this new, revised, and expanded understanding of broadloid is particularly useful in the Chinese context where the newspaper industry is predominated by a low-quality and stagnant tabloid sector in the absence of a Western-style quality press sector. In the meantime, the debate on the industry's future development has been deadlocked between polarised arguments from liberal and conservative critics. The broadloid approach as will be discussed further may shed some promising new light on the debate. 


\section{The rise and reign of the popular press sector}

The rise of the popular press sector from the mid-1990s and its replacement of the Party organ sector as the new dominant force in the daily newspaper market by the mid-2000s are arguably the most significant structural changes in China's newspaper industry in the era of reform. A thorough understanding of these changes thus becomes the logical starting point for a better understanding of the newspaper industry's more recent development and current stagnation. 'Popular press' or 'popular newspapers' in the Chinese context is defined in this study as market-driven and self-sufficient mass appeal daily newspapers. Most early popular press titles in China-the so-called 'metro papers' appeared in the mid1990s as will be discussed shortly—were broadsheets in terms of size but tabloids in terms of content and format. By the early 2000 s, nearly all these early titles were downsized to tabloids (in the form of a typical 'compact' or hybrid 'Berliner' size). In the meantime, most newly established popular newspaper titles since the 2000s adopted tabloid size from the very beginning of their publication. In this context, popular newspapers in China may be referred to as 'popular tabloids' too. 'Popular newspapers' are also used in this study from a comparative perspective to highlight their differences from propaganda-oriented, state subsided, and forced office subscription based 'Party organs' (mouthpieces of committees of the Chinese Communist Party [CCP] at different levels). In terms of size, format, and content preference, China's tabloid popular newspapers-in spite of the fact that they are still state-owned and subject to official censorship—are quite similar to their Western counterparts. In 
comparison, China's broadsheet Party organs have nearly nothing to do with the Western concept of serious-broadsheet press tradition that is characterised by its editorial independence, journalistic excellence, and emphasis on important hard news and watchdog journalism. In this sense, the 'popular newspapers vs. Party organs' scenario in the Chinese context does not really fit into the Western tradition of 'broadsheets vs. tabloids'. Having said this, the 'popular newspapers vs. Party organs' framework remains analytically crucial for the understanding of recent structural changes in China's newspaper industry.

The development of the popular press sector in post-Mao China can be divided into two major phases: the rapid development period from the mid-1990s to the mid-2000s as discussed below, and the era of stagnation and justification since the mid-2000s as will be discussed later. Historically, before being ruthlessly thrown into the so-called 'dustbin of history' in the early 1950 s by the newly established communist regime, popular newspapers had been in practice in China's major coastal cities for more than half a century (e.g., see Wang, 2009). For three decades under Mao's rule (1950s-1970s) when propagandaoriented Party organs became the dominant press genre, popular press was seen as a dangerous bourgeois idea banned in both journalism studies and practice (Ding, 2005). Even evening newspaper as a slightly less propagandaoriented press type was completely banned for more than a decade from 1966 to 1979 (Meng, 2002). Though re-emerged in the 1980s, evening papers merely resumed their traditional role as semi-reader oriented Party newspapers (Huang, 2001). In the meantime, full-fledged market-oriented popular press continued to 
remain absent. As a result, for more than 15 years from the late 1970 s to the mid-1990s, the daily newspaper market was largely dictated by morning Party organs (mostly run by CCP committees at central and provincial levels) and, to a much lesser extent, evening papers (mostly run by CCP committees at the municipal level). It was not until the mid-1990s after the CCP's official adoption of the 'socialist market economy' policy that popular press became politically possible and practically visible. This was marked by the emergence of the first string of full-fledged market-oriented and self-sufficient mass appeal daily newspaper titles widely referred to as 'city newspapers' or 'metro papers' (dushi bao) (Huang, 2001; Zhao, 1998). Essentially different from both traditional Party organs and evening papers, these popular press titles became instantly successful in the market for their fresh journalistic and business initiatives. Those initiatives included: a profoundly reader-oriented editorial approach, full-fledged market-driven and self-sufficient business model, independent distribution network, performance-based competitive personnel policy, a practice of sensationalism, strong focus on local news, and comprehensive subsidiary sections packed with soft and entertainment materials (Huang, 2001; Zhao, 1998). As mentioned earlier, though most early metro papers were broadsheets in terms of size, their obvious and often aggressive sensational editorial approach well qualified them as 'China's state-run tabloids' (Huang, 2001). While this emerging popular press sector of metro papers was timely captured in relevant early studies as cited above, there have been little serious follow-up studies since then. As a result, the research literature shows neither a clear 
trajectory of the sector's recent development nor a systematic analysis of the challenges that it faces.

According to an official survey supervised by the government's regulatory body on print media the National Press and Publication Bureau (NPPB), as of the end of 2006, there were 133 metro papers (NPPB, 2007a: 8-9). In other words, about 113 brand new titles were published during 2000 and 2006. The dramatic expansion of metro papers during this period put further market pressure on traditional evening papers. By the early 2000 s with more and more new metro paper titles entered into the daily newspaper market, the evening paper sector as a whole slipped even further and faced a crisis of legitimacy. As a result, the sector was forced to undergo a collective defection to the tabloid wonderland of metro papers in terms of its adoption of the latters' sensational journalistic approach and highly market-driven capitalist business model and even change in publication time from afternoon to morning. In 2004, a NPPB supervised survey report revealed China's top 20 'evening papers and metro papers' (Jin, 2005), the first of its kind in the People's Republic's journalism history. In 2005, the NPPB released China's first ever quasi-whitepaper on the development of the newspaper industry, in which 'evening papers and metro papers' were once again listed as a new and separate press category (Wang, 2005). These developments suggested the official recognition of the convergence of the two previously rather different newspaper categories. It is important to note that these two reports came at a critical moment, as 2004-2005 witnessed the peak of the most recent round of expansion of the newspaper 
industry driven predominantly by the strong growth of metro papers (NPPB, 2007c). Since then, the overall scale and structure of the industry have remained largely stable as evidenced by relevant subsequent surveys (e.g., Cui and $\mathrm{He}$, 2011; Cui and Zhou, 2009; Cui 2013). In this context, the convergence of evening papers and metro papers marked not only the formation of a larger and more influential popular press sector, but also the conclusion of an unprecedented overhaul of the general-interest daily newspaper market. The competition among three major players—-metro papers, evening papers, and Party organs-since the mid-1990s had by now largely drawn to a close with the triumph of an expanded popular press sector consisting of mainly metro papers and evening papers against the Party organ sector.

By the end of 2005, the popular press sector had held obvious supremacy against the Party organ sector in the marketplace as shown clearly in relevant NPPB survey reports. For example, in 2005, the popular press sector had 287 titles total, compared with the Party organ sector's 438 titles (a 151 title difference). However, in the same year, the former accounted for more than $40 \%$ of total copies of newspapers printed (compared with the latter's share of 22.1\%) and more than $60 \%$ of total sheets of newsprint used (compared with the latter's share of $18.1 \%$ ) nationwide. In terms of its financial performance, the popular press sector accounted for nearly $47 \%$ of the newspaper industry's overall revenue and $50 \%$ of the industry's total pre-tax income (compared with the Party organ sector's share of 32\% in both categories) (NPPB, 2007a, 2007b, 2007c, 2007d). Among the 19 newspapers whose turnover passed the RMB500 million 
mark in 2005, 14 were popular titles (NPPB, 2007d: 94-95). In the same year, there were 25 popular press titles whose average printed copies per issue passed the 500,000 mark (NPPB, 2007c: 53,56 ), proving themselves truly the readers' choice. Such comparisons are even more significant when considering the fact that the popular press sector was financially self-sufficient and sold predominantly by private subscription and retail sale. In contrast, the Party organ sector relied predominantly on government subsidy and forced office subscription. In this context, the two sectors were virtually incomparable. The biggest challenge of the Party organ sector was that it had by now had nearly nothing to do with the general public's everyday information needs as it had been completely driven out of the private subscription and retail sale market. This had literally declared the journalistic death of the Party organ sector as a whole.

\section{New (and old) challenges and the debate between idealists and pragmatists}

Few would deny that historically the rise and reign of the popular press sector at the expense of the Party organ sector in China was a positive journalistic development. But this was by no means to suggest the disappearance of many old concerns as well as new challenges facing China's newspaper industry. As a matter of fact, as early as the early-2000s when the popular press sector was still rapidly expanding, concerns about its long-term journalistic and financial sustainability started to surface. Politically, government press censorship 
remained intact. Press competition might have expanded the industry's freedom of selling sensational and soft materials for profit but offered them little editorial independence in reporting important political and social issues. Structurally, like the Party organ dominated daily newspaper market before, the now tabloiddominated market did not offer much journalistic diversity either. The once fresh and creative tabloid journalistic approach (compared with the propagandaoriented dull and dry traditional Party journalistic approach) practiced by the first metro papers in the 1990s had by now largely become a new hegemonic journalistic doctrine. This high degree of mimetic isomorphism also implied the approach as a business model—boosting circulation and advertising by playing the sensational card-was losing its momentum. This explained why the income growth of the sector as a whole started to slow down and certain popular press titles even reported negative growth (NPPB, 2007c). The overly money-driven journalistic culture and associated poor professional and ethical standards across the sector also caused widespread outcries from press regulators, media critics, and ordinary readers alike (e.g., see Huang, Knight and Davies, 2002; Rui, 2007; Wu, 2005; Zheng and Chen, 2004). In the meantime, the fast growing new-media sector, being capable to provide audiences with not only much quicker and more up-to-date news but also all sorts of sensational and soft materials, was also imposing growing pressure on the print media sector. It was in this context that a high-profile sector-wide press campaign under the banner of 'towards a mainstream press' (zouxiang zhuliu baozhi) started in about 20022003. Suddenly, nearly all popular press titles were declaring that they were 
transforming themselves into 'mainstream' papers. Meanwhile, some newly established popular titles (such as the Beijing News or Xin Jing Bao published in 2003) from very beginning of their publication claimed that they were mainstream papers rather than tabloid titles.

The term 'mainstream press/newspapers' has remained a hot topic in Chinese journalism since the early 2000s though Chinese critics have remained deeply divided over what the term really means. In Western journalism, the term—being often used in comparison with independent or alternative newspapers-has been conventionally used to refer to those press titles that serve either a large popular, in the case of tabloids, or elite, in the case of broadsheets, readership (e.g., Kenix, 2011). In other words, conventional Western understanding of the term contains both mainstream serious/quality papers and mainstream tabloid or popular papers. In this context, China's popular press titles in the early 2000 s were truly mainstream papers already. But interestingly, Chinese critics define mainstream newspapers very differently. Liberal critics, for example, see mainstream press as mainstream quality papers (zhuliu dabao) such as the New York Times in the United States only. They also rather confusingly view mainstream press as an opposite and superior press category to popular press (e.g., Fang, 2006; Qi, 2011; Zhao, 2006; Yu, 2013). ${ }^{1}$ Accordingly, for them, the ultimate goal of the 'mainstream press' campaign is to transform China's popular press sector into a Western-style serious press model. In contrast, in the eyes of the popular press sector itself and conservative media critics, mainstream press simply means a less sensational and more common- 
sense oriented tabloid journalism that aims primarily at responding to the rapidly changing market environment. By the end of the 2000s, most popular titles had proudly declared that they had successfully transformed themselves into an advanced and superior 'mainstream' press model. In other words, they were now quality papers instead of low-quality tabloids. But in actuality, they were still essentially based on a sensationalism-oriented—-though comparatively more balanced and less aggressive-tabloid journalism. To put it another way, it was a modified version of tabloid journalism that aimed to serve a broader readership (not just the low-end readership market) with more diverse news coverage (more non-critical and often softened hard/general news and commentary pieces on top of sensational stories and soft materials) in a less aggressive manner (in terms of both overall editorial orientation and news narrative). ${ }^{2}$ Unsurprisingly, liberal critics have accused this form of mainstream press as 'fake' as it has little to do with a Western-style quality press model (e.g., see Bao, 2003).

The problem of this on-going debate on an ambiguous 'mainstream' press model among Chinese critics is multiple. While it is true that the popular press sector's self-praise of the 'mainstream press' campaign was far-fetched, liberal critics' sweeping criticisms of the campaign do not make much sense either. Liberals must understand that to overstate quality press's superiority to popular press and call for a wholesale transformation of the popular press sector into a Western-style serious press model is both elitist and utopian in the Chinese context. It would be naïve to ignore the diverse interests and needs of various readerships in the vast Chinese newspaper market. Historically, the significance 
of the rise of popular press since the mid-1990s lies exactly in its determined and effective breaking away from the powerful and often propaganda-oriented elitist tradition of modern Chinese journalism (e.g., see Cheek, 1989). China's liberal critics should think twice before imagining a rosy prospect for a large serious press sector for an elitist readership in China. As experienced by South Korea (e.g., see Lee, 1997), Taiwan (e.g., see Rawnsley GD and Rawnsley MT, 2004), and many Eastern European countries (e.g., see Wyka, 2008), even in a postdemocratised context there will likely be little room for such a press sector to financially survive in the ruthless marketplace. In the meantime, an economically comfortable middle class readership may become politically apathetical and not necessarily embrace such press (e.g., see Sim, 2001). China's liberal critics have also seemingly failed to realise that even in established democracies with a long and powerful serious press history, the traditional broadsheet press sector is under growing market pressure and more and more broadsheets are seemingly forced to undergo a broadloidisation process (e.g., see Franklin, 1997, 2005b). Still, liberal critics' call for a Western-style quality press in current China is politically unrealistic and journalistically challenging. Politically, it is hard to imagine running a New York Times like title under authoritarianism, let alone to transform the whole popular press sector into a Western-style quality press model. Journalistically, a liberal quality press would need strong support of a highly professional journalistic workforce, something China's press industry lacks. An elitist press approach is better to be seen as one particular journalistic 
genre rather than a superior goal model for the transformation of the popular press sector.

On the other hand, the popular press sector and China's conservative critics must also understand that it can hardly be seen as journalistically and socially healthy when a country's daily newspaper market is predominated by hundreds of highly money-driven tabloids in the absence of a rival quality newspaper sector. Nor would it be sufficient to respond to the major challenges facing the sector if they are content with just achieving a less sensational tabloid journalism. Those challenges, as mentioned earlier, have mainly manifested themselves in three interrelated areas: the homogeneity of the sector's journalistic genre, serious concerns over the sector's professional-ethical standards, and growing worries about the sector's financial sustainability. Based on relevant survey reports, the overall market performance of the popular press sector, together with that of the newspaper industry as a whole, has gradually been losing momentum since the early 2000s. For example, in 2012, the newspaper industry's overall circulation dropped 3.09\% (Tian, Cai and Cui, 2013: 92), while its advertising income was down by $7.5 \%$, its worst performance in 30 years (Yao, 2013: 84). In 2012, the industry was also the only sector across all categories of mass media in China that experienced negative growth in advertising income (Yao, 2013: 82). Accordingly, the popular press sector's circulation and advertising income also tumbled (Tang and Zhuo, 2013: 76; Tian, Cai and Cui, 2013: 93). In particular, as its private subscription market shrinks, popular newspaper as a particular press category as long-time favourite of major 
advertisers has now been ruthlessly removed from their 'priority/core media' list (Cui, 2013: 9).

Low professional and ethical standards have been a lasting concern of the popular press sector. But both sides of the 'mainstream' press debate have failed to effectively address the issue. While liberal critics have put all their hope on a democratic political change, pragmatists, particularly the popular press sector itself as a whole, have largely taken an approach of keeping one eye open and the other closed. As a result, they all seemingly intend to believe that there is little that one can do with this issue now. Typically, for example, though anti-sensationalism was a major goal of the 'mainstream press' campaign, the sensationalism mentality still remains highly visible in leading popular titles' dayto-day coverage. The only difference is that sensationalism, once being exploited in a rather crude and aggressive way, has now been strategically demystified, normalised, and formalised by the sector. It may now take such forms as a dramatic (in terms of page layout) and sensational (in terms of topic/content preference) front page followed by more normal inside pages, a normal story with a sensational heading and/or playful writing style, and overwhelming soft and general news against important hard news and critical/investigative reports. In the meantime, very few popular titles would miss the opportunities of sensationalising major breaking news events, both domestic and international, from natural disasters to crime stories. Typically, for example, on 15 August 2012, a most-wanted serial killer suspect named Zhou Kehua was shot dead by police in Chongqing. Astonishingly, nearly the whole popular press community 
was hyped by this major crime news and responded with swift and utterly sensational coverage of it. A big bold heading 'Ferocious Bandit Zhou Kehua Was Shot Dead' accompanied by a photo of Zhou's body lying prone on the blood-bathed floor of the scene, for example, occupied the whole upper quarter

of the front page of the Guangzhou-based Southern Metro News (Nanfang Dushi $B a o$ ) in the following day. Such behaviour illustrates typically the worrying professional-ethical standards of the popular press sector, considering the fact that the Southern Metro News has been widely seen as an industrial leader that sets a benchmark for many other tabloid titles in China.

In short, the 'mainstream press' campaign lacks the theoretical capability to systematically address the major challenges of the popular press sector, as both liberal and conservative critics have failed to advance a visionary and workable reform program. Being pragmatic without imagination, just like being idealistic without strategy, jeopardises the potential for theoretical innovation. And this discussion leads to my call for introducing the broadloid press approach into China's popular press sector.

\section{Broadloid journalism as a forward-looking pragmatic alternative}

As discussed beforehand, the term broadloid in this study is reinvented as a general press approach that may be used in diverse political and journalistic contexts. Specifically, this understanding of the term suggests that broadloidisation may be achieved via either the normative path of the 'dumbing down' of a serious-broadsheet paper, or the 'wising up' of a tabloid title as an 
alternative path. It also means that while the Western practice of broadloidisation via the first path may be seen as the ideal, normative model, there may be a variety of transitional or alternative versions of practice in the case of the second path under different social, political, and journalistic systems. And very importantly though, this flexibility in terms of the specific path of, and approach to, broadloidisation should always be underpinned by the core value of boradloid as a popularised quality press approach that has quality in its blood and readability in its mind. In the Chinese context, the liberating and empowering potential of this dynamic understanding of the term to the further reform of China's popular press sector can be viewed from a number of important aspects:

First, the approach may help revitalise the debate on the sector's further reform by shifting the focus of the debate away from the flawed and ambiguous 'mainstream' press approach and serve as the best possible reform strategy for the sector under the current political, market, and journalistic conditions in China. In comparison with broadloidisation in the West as a result of traditional broadsheet newspapers' deliberate 'dumbing down' (e.g., Franklin, 1997, 2005b), introducing the broadloid concept into China's popular press sector would require the sector to 'wise up' by substantially improving its professional standards. The sector's current editorial orientation of treating readers as consumers by feeding them with what Franklin (2005b: 137) has called 'McJournalism' (a highly standardised and packaged, market-driven superficial journalism on the principles of efficiency, calculability, predictability and control) is not only socially problematic, but also evidently running out of steam in the 
market. Competing with new media on soft-news oriented McJournalism is hardly a wise strategy in long term for China's tabloids. The broadloid approach as a sensible and meaningful alternative strategy may lead them to a new and more balanced journalistic direction and allow them to inform readers as both consumers and citizens with both reader-friendly hard news on, and insightful news analysis of, important public interest events and issues and soft-news and -materials. The approach would also require the popular press sector to advocate newspaper readability based on sensible professional standards and taste rather than cheap sensationalism. As a press concept based on forwardlooking pragmatic thinking, the approach would also give individual popular titles the flexibility to negotiate with a range of complex contextual factors. On the one hand, they will be theoretically held accountable against relevant professional principles and work towards the normative Western style of broadloid or a meaningful alternative in long term. On the other hand, they may work out a specific strategy of reform based on circumstances they are facing in a local context in the process of broadloidisation. Differing from liberal critics' exciting yet unrealistic suggestion of directly transforming the popular press sector into a Western-style serious press model and pragmatists' content with the sector's current status quo, the broadloid approach in the Chinese context focuses primarily on improving the sector's basic professional standards while encouraging the sector to continue to push the boundaries of China's press censorship. 
Second, the broadloid approach may also help China's popular press sector have a better understanding of journalistic professionalism. Many Chinese journalists and media critics have seemingly mixed press freedom and journalistic professionalism up, failing to realise that they are two connected but also very different issues. This is typically reflected in their passive response to the popular press sector's poor professional-ethical standards, as they intend to believe that this issue would be automatically solved when press freedom in China becomes reality. But it should be noted that press freedom may help but does not necessarily guarantee the achievement of a high standard of professional journalism. The first and foremost function of press freedom is to provide legal protection for the practice of watchdog journalism. But watchdog journalism should not be seen as the only and in certain circumstances even the predominant meaning of journalistic professionalism, as the term also implies many other very important codes such as the press's responsibility of providing audiences with truthful, accurate, and objective or balanced news reports and making its own journalistic and business practices transparent and accountable to the general public. From the perspective of the broadloid approach, while the practice of systematic and independent watchdog journalism still remains politically impossible in current China, individual press outlets and journalists could substantially improve their performance in these less politically charged areas. In other words, broadloid as a press approach sees the development of journalistic professionalism as a matter of not only radical institutional but also gradual cultural changes. A democratic political change may instantly bring 
about a free, but not necessarily highly professional and ethical, press, as behavioural change of individual journalists and media outlets may take a long time. The approach thus calls for direct actions (being professionally and morally self-conscious and -disciplined) from individual journalists and media outlets in their everyday journalistic practices. Primarily, they must seriously deal with the infamous 'four common sins' (si da gong hai)—fake stories, paid journalism, low journalistic taste, and unethical/illegal advertisements-that still widely exist across China's journalism industry including the popular press sector (Rui, 2007; Wu, 2005). A 2004 survey sponsored by the Ministry of Education found that by average only about $33 \%$ of the more than 1,000 surveyed journalists clearly opposed various forms of paid journalism (Zheng and Chen, 2004). China's journalism community has little excuse to justify such behaviours by merely blaming the country's one-party political system without mirroring itself. News media and journalists in China as a privileged industry and profession hold enormous political, journalistic, and commercial resources and power and are hardly merely victims of the country's authoritarian system; rather, to certain extent, they are the beneficiaries of the system and part of its many problems too.

Third and last, the broadloid approach may also serve as a meaningful pathway for China's newspaper journalism to be more in line with international/Western journalistic norms in future. The tabloidisation trend of traditional broadsheet newspapers in the West has been a much-debated issue among critics. While critical scholars see the emergence of broadloids as a clear 
sign of the decline of quality journalism in the West, more realistic critics argue that this dumbing down thesis as a 'dominant critical orthodoxy' (McNair, 2003: 52, cited in Temple, 2006: 259) is little more than an overstated elitist assumption. In the words of Greenslade (2003), this thesis is based on romanticised memories of 'those legendary good old days' of broadsheet newspapers. They argue that the emergence of broadloids should instead be seen as a constructive response of traditional broadsheet newspapers to rapid demographic, social, cultural, and media changes in recent decades. Instead of being dumbing down, traditional broadsheets have actually been 'dumbing up' as broadloids (see Franklin, 2005b: 137). It is thus a dumbing down that is 'good for you' (Temple, 2006). While this 'dumbing down/up' debate seems far from conclusive, two points stand out. One is that, while critics remain divided about the cause and nature (in terms of possible journalistic consequences) of the tabloidisation trend, very few of them deny the trend itself or have much idea about how this trend may be contained (as far as some critical scholars concerned). Two, some leading Western broadsheets' broadloidisation experiment to date has at least seemingly been well received by the industry and the market as well as more open-minded critics. Again, as Greenslade (2003) argues, '[t]he tabloids haven't come close to providing the range of materials now regularly offered by the broadsheets', and reforms in The Times and The Guardian in Britain 'discovered that they could incorporate the tabloid agenda without unduly compromising their authority and their central mission to inform and explain'. Unlike broadsheets in the West with heavy historical burden on 
their shoulders when attempting to shift to the broadloid model, introducing the broadloid approach into China's tabloid-monopolised newspaper industry would be certainly a positive move. It is interesting to note that broadloid is seemingly increasingly replacing traditional broadsheet as the new, standard version of quality newspapers—or 'quality papers 2.0 ' in a trendy way—in many Western countries. In the meantime, facing similar neoliberal economic and rapidly changing communication technological and socio-demographic challenges (regardless of China's one-party political system), the age of having a large Western-style traditional serious-broadsheet press sector has largely and probably forever bypassed China. In this context, it becomes logical for China's popular press sector to waste no time to start to seriously think about its own quality papers strategy through its own way of broadloidisation.

There is no doubt that China's popular press sector still has a long way to go before a mature, professional broadloid journalism may be installed. Compared with traditional broadsheets' popularisation in the West, China's tabloid titles would have to work much harder to find ways to substantially improve their professional performance while continuing to push the boundaries of government censorship. While this is a complex and challenging task that may be achieved only in a gradual and discursive way, a broadloid journalism in China does not have to start from scratch. Some encouraging and useful practices that the popular press sector achieved in its 'mainstream press' campaign may be taken as the starting points. For example, a visible increase in hard/general news in some leading popular press titles' everyday news coverage 
may be seen as a small but positive development. Moreover, while the practice of watchdog journalism is still under huge political pressure, such practice is seemingly getting some momentum at the micro level in the latest decade as reflected typically in a series of high profile clashes between certain popular titles and CCP propaganda officials. ${ }^{3}$ There are also signs to suggest that journalistic professionalism is staring to gradually emerge in a small number of Chinese media outlets (e.g., see Chen, 2008; Lu and Pan, 2002). In addition, some leading popular titles' experiment with a popular but generally non-sensationallydriven approach is worth paying close attention too. Typically, the Beijing News as referred to earlier has shown a great effort in this regard as visibly reflected in its everyday news coverage (the paper's free digital version is available at: http://www.bjnews.com.cn/). In spite of this, the newspaper has been well received in the extremely competitive Beijing press market with a current average daily circulation of 776,000 copies. ${ }^{4}$ This is significant in the Chinese context as it implies the emergence of a very different readership that is no longer easily held captive to sensational tabloid journalism. Having said this, neither the popular press sector nor the scholarship of Chinese journalism studies as a whole has paid close and serious theoretical interest in broadloid as a press concept and its empowering potential to China's newspaper journalism. In fact, even the Beijing News was no exception of playing the sensationalism card from time to time (for example, like many of its peers, the paper just could not help exploit the Zhou Kehua case as referred to earlier with sensationalised story and photo about the case on its front page following the event). It is my 
wish to use this study to raise the theoretic urgency to introduce the broadloid concept into China's tabloid-dominated newspaper industry and foster further debate on its future development.

\section{Beyond the status quo and liberal idealism: Some concluding words} In my discussion above, I have argued that the rise of China's popular press sector from the mid-1990s and its replacement of the Party organ sector as the new dominant force of China's print journalism by the mid-2000s are historically significant in contemporary Chinese journalism. I have also argued that there is however a lack of academic innovation in tackling the sector's recent and ongoing stagnation. Aiming at theoretically revitalising the currently deadlocked debate on the sector's further reforms between conservative pragmatists and liberal idealists, I have called for adopting a broadloid approach to better address the challenges that the sector faces. Theoretically, my central argument is threefold. First, ultimately, boradloid as a general press approach aims to bring about a popularised quality journalism by striking a dynamic balance between newspaper quality and readability. This may be achieved via broadloidisation of either traditional serious-broadsheet papers (the 'dumbing-down' path) or tabloids (the 'wising up' path). Second, broadloid as a press approach not only holds democratic spirit and professional passion, but also pays close attention to practical challenges in the real world of journalism. It thus holds the conceptual capacity and flexibility to tackle diverse challenges of contemporary journalism in divers contexts. Third and last, for reasons mentioned above, the approach may 
well serve as the best possible theoretic framework for the further reforms of China's stagnant popular press sector. While the practice of broadloid journalism itself may not necessarily lead to a free press in China, it could help improve the overall professional standards of the tabloid dominated newspaper industry and make it more journalistically vibrant and sustainable. This (along with other factors, particularly a democratic political change), in return, would positively contribute to the achievement of a free press with high professional standards in China in the long run.

\section{Notes}

\footnotetext{
${ }^{1}$ Most of these Chinese critics have attempted to back their understanding of the term up by referring exclusively to Noam Chomsky’s (1997) 'What Makes Mainstream Media Mainstream'. Interestingly, though Chomsky did imply 'mainstream' media as 'elite' media in the essay, he provided no justification for his suggestion, nor did he clearly define the term. Moreover, while these Chinese critics conveniently treat the essay as the original and authoritative reference to 'mainstream media', the essay is in fact just a free-style reflective piece and a radical critique of American elite media such as the New York Times (and other hegemonic powers in the American society) — exactly the type of media these Chinese critics envy.

${ }^{2}$ These points are critically synthesised from relevant discussions by some Chinese media critics (e.g., see Lai, 2009; Qi, 2011; Zhao, 2006) and this author's critical reading of dozens of China's leading popular press titles' everyday coverage.
} 
${ }^{3}$ A recent example is the so-called 'New Year editorial incident'. In early January 2013, journalists from the reformist Southern Weekly (Nanfang Zhoumo) went on strike in a protest against local authorities' censorship of the paper's New Year editorial calling for constitutional reforms in China. Hundreds of readers also gathered outside its office or make comments online to show their support to the paper (search online for more details).

${ }^{4}$ This circulation figure is taken from the newspaper's online 'about us': http://i.bjnews.com.cn/gywm.html

\section{References}

Bao HB (2003) An analysis of the pseudo-mainstreaminisation trend of metro papers. Xinwen Jizhe (Shanghai Journalism Review) 10 (in Chinese). Available at: http://xwjz1.eastday.com/epublish/gb/paper159/200310/class015900002/hwz64352 5.htm

Cheek T (1989) Redefining propaganda: Debates on the role of journalism in post-Mao Mainland China. Issues and Studies XXV(2): 47-75.

Chen Y (2008) A comparison of two paradigms of journalistic professionalism: The cases of the Southern Weekend and the Caijing Magazine. Guoji Xinwenjie (International Journalism) 8 (in Chinese). Available at: http://wenku.baidu.com/view/7c6d29f34693daef5ef73ded.html?from=relatedhttp:// wenku.baidu.com/view/7c6d29f34693daef5ef73dcd.html?from=related

Chomsky, N. (1997) What Makes Mainstream Media Mainstream. Z Magazine. Available at: http://www.chomsky.info/articles/199710--.htm 
Cui, BG (2013) 2012 China media development report. In: Cui BG (ed) 2013 Blue Book of China's Media. Beijing: Social Sciences Publishing (in Chinese), 1-16.

Cui BG and He DM (2011) 2011 Chinese media industry development report. In: Cui BG (ed) 2011 Chinese Media Industry Development Report. Beijing: Social Sciences Publishing (in Chinese). Available at: http://guoqing.china.com.cn/node_7140590.htm

Cui BG and Zhou K (2009) Seeking opportunities in challenges: Media in China 2009. In: Cui BG (ed) 2009 Chinese Media Industry Development Report. Beijing: Social Sciences Publishing (in Chinese). Available at: http://news.china.com.cn/txt/200908/05/content_18271043_2.htm

Ding GN (2005) Chinese News Media History. Beijing: Higher Education Press (in Chinese).

Fang YF (2006) Four key issues on 'mainstream media'. Xinwen Jie (The Press Circles) 6 (in Chinese). Available at: http://xwj.scol.com.cn/1lzy/20061115/2006111532352.htm

Franklin B (1997) Newszak and News Media. London and New York: Aronald.

Franklin B (2005a) Broadloid. In: Franklin et al. (eds), Key Concepts in Journalism Studies. Thousabd Oaks, CA: SAGE, pp. 28-29.

Franklin B (2005b) McJournalism: The local press and the McDonaldization thesis. In: Allan S (ed) Journalism: Critical Issues. New York: Open University Press, 137150. 
Greenslade R (2003, October 20) How the broadsheets brightened up. The Guardian. Available at:

http://www.guardian.co.uk/media/2003/oct/20/pressandpublishing.bookextracts

Huang CJ (2001) China's state-run tabloids: The rise of 'city newspapers'. International Communication Gazette 63(5): 435-450.

Huang CJ (2007) Trace the stones in crossing the river: Media structural changes in postWTO China. International Communication Gazette 69(5): 413-430.

Huang CJ, Knight A and Davies CL (2002) Beyond Party propaganda: a case study of China's rising commercialised press. Ejournalist (ejournalist.au.com) 2(1): 1-21.

Jin B (2005) An analysis of China's top 20 evening papers and metro papers in 2005. Zhongguo Baoye (China Newspaper Industry) 8 (in Chinese). Available at: http://wenku.baidu.com/view/836cd836a32d7375a4178048.html

Kenix, LJ (2011) Alternative and mainstream media: The converging spectrum. London and New York: Bloomsbury Academic.

Lai DB (2009) The Southern Metro News's transformation into a mainstream newspaper. Qingnian Jizhe (Young Journalists) 9 (in Chinese). Available at: http://www.qnjz.com/cmga/200909/t20090930 5094026.htm

Lee CC (ed) (2003) Chinese Media, Global Contexts. London and New York: Routledge Curzon.

Lee JK (1997) Press freedom and democratization: South Korea's experience and some lessons. International Communication Gazette 59(2): 135-149.

Lu Y and Pan ZD (2002) Imagining professional fame: Constructing journalistic professionalism in social transformation. Journalism Studies 71 (in Chinese): 17- 
59.

McNair B (2003) News and Journalism in the UK. London: Routledge.

NPPB (2007a) The development of newspaper industry remains stabile. In: Lin J and

Feng YM (eds) 2007 Chinese Newspaper Industry Development Report. Beijing:

Social Sciences Publishing (shehui kexue wenxian chuban she), 4-22 (in Chinese).

NPPB (2007b) Major indexes of newspaper industry changed little. In: Lin J and Feng

YM (eds) 2007 Chinese Newspaper Industry Development Report. Beijing: Social

Sciences Publishing, 23-42 (in Chinese).

NPPB (2007c) Progress achieved across different sectors of the newspaper industry. In:

Lin J and Feng YM (eds) 2007 Chinese Newspaper Industry Development Report.

Beijing: Social Sciences Publishing, 43-86 (in Chinese).

NPPB (2007d) The overall financial situation of the newspaper industry is healthy. In:

Lin J and Feng YM (eds) 2007 Chinese Newspaper Industry Development Report.

Beijing: Social Sciences Publishing, 87-110 (in Chinese).

Pan Z (2000) Improvising reform activities: The changing reality of journalistic practice

in China. In: Lee CC (ed) Power, Money, and Media: Communication Patterns

and Bureaucratic Control in Cultural China. Evanston, IL: Northwestern

University Press, 68-111.

Qi AJ (2011) What is 'mainstream media'? Xiandai Chuanbo (Modern Communication) 2 (in Chinese): 50-53.

Rawnsley GD and Rawnsley MT (2004) The media in Taiwan: Change and continuity.

China Perspectives 56: 46-55. 
Rui BF (2007) Media, market, and journalistic ethics. Xinwen Jizhe 8 (in Chinese).

Available at:

http://xwjz.eastday.com/eastday/xwjz/node213770/node213771/u1a3009649.html

Sim SF (2001) Asian values, authoritarianism and capitalism in Singapore. Javnost-The Public 8(2): 45-66.

Sun ZY and Liu TT (2009) Chinese journalism review, 2008 (part 2). Xinwen Jizhe, 1.

Retrieved from

http://xwjz.eastday.com/eastday/xwjz/node309763/node309765/u1a4093867.html

Tang XJ and Zhuo HY (2013) Keywords on China's newspaper industry in 2012. In: Cui

BG (ed) 2013 Blue Book of China's Media. Beijing: Social Sciences Publishing (in Chinese), 75-81.

Tang, Y (2012, July 10) Newspaper circulation still on the rise. China Daily. Available at: http://www.chinadaily.com.cn/china/2012-07/10/content_15563141.htm

Temple M (2006) Dumbing down is good for you. British Politics 1: 257-273.

Tian K, Cai ZP and Cui JH (2013) An analysis of 2012 Chinese newspaper circulation market. In: Cui BG (ed) 2013 Blue Book of China's Media. Beijing: Social Sciences Publishing (in Chinese), 92-107.

Wang GQ (2005) 2005 China newspaper industry development annual report (in Chinese).www.people.com.cn. Available at: http://www.1a3.cn/cnnews/cmdc/200909/7322.html

Wang J (2009) Imagining citizenship: The Shanghai tabloid press, 1897-1911. Twentieth Century China 35(1): 29-53. 
Wu GP (2005) The practice of false journalism worsening. Xinwen Jizhe 10 (in Chinese).

Available at:

http://xwjz.eastday.com/eastday/xwjz/node89718/node89719/userobject1ai150300

$\underline{0 . h t m l}$

Wyka AW (2008) Journalistic standards and democratisation of the mass media in Poland, Hungary and the Czech Republic. In: Keeble R (ed.) Communication Ethics Now. Leicester: Troubador Publishing Ltd., pp. 93-108.

Yao L (2013) An analysis of 2012 China newspaper advertising market. In: Cui BG (ed) 2013 Blue Book of China's Media. Beijing: Social Sciences Publishing (in Chinese), 82-91.

Yu, GM (2013) Lessons of the New York Times: How to run mainstream media? Sina.com.cn. Retrieved from http://news.sina.com.cn/m/2013-01-29/102526149421.shtml

Yu HQ(2011)Doing Chinese media studies: A reflection on the field's history and methodology. Media International Australia 138: 66-79.

Zhang SI (2010) Chinese newspaper ownership, corporate strategies, and business models in a globalizing world. International Journal on Media Management 12(3 and 4): 205-230.

Zhao KQ (2006) Mainstream media and the mainstreaminisation of the media. Xinwen Zhishi (Knowledge on Journalism) 3 (in Chinese). Available at: http://www.cqvip.com/QK/82115X/200603/21744062.html

Zhao YZ (1998) Media, Market and Democracy in China: Between the Party Line and the Bottom Line. Urbana: University of Illinois Press. 
Zhao YZ (2000) From commercialization to conglomeration: The transformation of the Chinese press within orbit of the Party state. Journal of Communication 50(2): 326.

Zhao YZ (2008) Communications in China: Political economy, power and conflict. Lanham, MD: Rowman and Littlefield.

Zheng BW and Chen X (2004) Media workers' attitude on 'paid journalism'. Xinwen Jizhe 5 (in Chinese). Available at:

http://xwjz.eastday.com/eastday/xwjz/node19085/node19087/userobjectlai221518. $\underline{\mathrm{html}}$ 